\title{
Motives behind Networking on Social Media and Subsequent Gossip Propensity: A Causal Analysis
}

\author{
Erum Nadeem \\ Dept. of Management Sciences, SZABIST \\ PO Box 345004, Dubai, United Arab Emirates \\ E-mail: erum123@outlook.com \\ Paras Shehzad \\ Dept. of Management Sciences, SZABIST \\ PO Box 345004, Dubai, United Arab Emirates \\ E-mail: sweetychill@hotmail.com \\ Zubair Azam \\ Dept. of Management Sciences, SZABIST \\ PO Box 345004, Dubai, United Arab Emirates \\ E-mail: zubairazam6@gmail.com
}

Received: April 27, 2016

10.5296/jmr.v8i3.9386
Accepted: May 30, 2016 Published: July 1, 2016

URL: http://dx.doi.org/10.5296/jmr.v8i3.9386

\begin{abstract}
Keywords: Social networking, social Research study aims to investigate the nature, strength and direction of associations between motives of using social networking sites and gossip propensity. Data was collected from 240 customers through convenience sampling. Instrument was adapted from existing body of knowledge. Multiple regression and structural equation modeling was performed to quantify the associational relationships. Hypotheses claiming relationship between Motives of social media usage and gossip propensity are proved. Results indicate positive and direct change being caused in gossip propensity by four motives of social media usage. This study offers new empirical support for the proposition that individuals who use social media tend to actively participate in gossiping about brands,
\end{abstract}




\section{Macrothink}

Journal of Management Research ISSN 1941-899X 2016, Vol. 8, No. 3

companies, incidents and individuals. As such, findings from this study aspires managers to develop social media strategies to increase brand buzz, referral value and net-promoter score. media, information motive, friendship motive, entertainment motive, social enhancement, Gossiping.

JEL Code: M310 


\section{Introduction}

An explosive growth in social media facilitated its users to arrange themselves among different social networks which were further boosted by social networking sites (Hajli, 2013; Okazaki, Rubio, \& Campo, 2014). People interact on social networking sites for various purposes, and research studies (Griffith, 2015; Kurland \& Pelled, 2000; Linde, 2001; S. Song, 2012) substantiate the power and importance of social networking in organizational knowledge transfer among employees as well as to external stakeholders like customers. These interactions among organizational members can lead to rumors and gossips which may, further, have positive or negative influence on organizational culture as well as on organizational reputation (Clegg \& van Iterson, 2009; Kurland \& Pelled, 2000; Linde, 2001). On the other hand, gossips and rumors being shared among consumers can lead towards an increase in brand buzz making brand campaigns viral in the marketplace (Archer-Brown, Piercy, \& Joinson, 2012; Kotler \& Keller, 2014). Anthropologists have historically considered gossip as a tool to maintain group interests (K. M. Kniffin \& Sloan Wilson, 2010; Kevin M. Kniffin \& Wilson, 2005) whereas psychologists have tended to consider the use of gossip to advance individual interests (Griffith, 2015; McAndrew, Bell, \& Garcia, 2007). However, management researchers have tried to explore the motives of gossiping among employees and their subsequent organizational implications (Griffith, 2015). Advent of social media has triggered the gossip propensity both among employees and customers (Griffith, 2015; Hajli, 2013; Okazaki et al., 2014) and in order to truly harness the power of social networking and social collaboration, companies need to understand the motives people generally have while using social media.

Present research study intends to explore people's motives of using social media and their respective association with gossip propensity. In this way, researchers aim to generate postulations useful for companies to increase social identification for customers which may lead to increased net-promoter score and referral value.

This research can be helpful in examining how online gossip and related behaviors of individual can differ across different SNSs. For example, different perceptions, responsiveness, attitudes as well as behavioral intents may be discovered according to the different motive from usage of SNS (L. Z. Song, Song, \& Di Benedetto, 2009; S. Song, 2012). Further implications can also be conducted from this research study. The study provides with information that how the habit of using social sites is intensifying the propensity to gossip.It can, further, assist the readers that whether their motive behind the usage of social networking sites is affecting individual life. If it is, then to what extent they possess the tendency to gossip. Study also intends to provide managerial inferences for professionals as well as academicians.

\section{Literature Review}

Gossip generally explained, news will be info on the revolutionary, deviant qualities or even behavior's connected with others(R. I. M. Dunbar, 2004). SNS users usually chitchat about what is happening of their friends' life, seeking novel, amusing or even scandalous anecdotes about all of them (Rosnow \& Foster, 2005). 
Many people take gossip as of a negative word of mouth but in actual gossip are usually seen as entirely self-serving habits directed at manipulating other people as well as influencing them in certain detrimental method. However, some researchers argue that gossip is determined and important to social functioning (R. I. M. Dunbar, 2004; R.I.M. Dunbar, Arnaboldi, Conti, \& Passarella, 2015; Rosnow \& Foster, 2005). Gossip is an idle talk about personnel or private concerns of others which can be positive or negative way. Gossip play an important role in social media, individuals' gossip for many reasons as discussed above. Gossiping helps people to understand about other people perspective regarding different things in life.

Gossip might actually produce achievable the actual usually excessive amounts of co-operation that are observed in human societies (S. Song, 2012). The reason are that gossip might help people to achieve a much better idea of others of their surroundings by letting them obtain information regarding the actions these men and women even if many people cannot right monitor the behavior's.

As today, gossip tents the foremost activity in people life. Gossip helps individual to create an interest in one's life. This research lead upon that individuals perceive gossip to provide useful or exchange information with one another, to keep in touch with other individuals, to get entertained or to get motivated that works to make individual feel good about themselves and to maintain self-esteem. Furthermore, it claims that users expend many their speaking lifestyle swapping chat of just one variety or even one more (Asiegbu, Powei Daubry M, \& Iruka, 2012; R.I.M. Dunbar et al., 2015; Okazaki et al., 2014).

It is believing that gossip is able to improve people's understanding of their social environment. It may help the users to pledge the threats posed by hackers so a high level of cooperation can be build (Rosnow \& Foster, 2005; Vohs et al., 2014). The use of social media has become the widespread practice particularly amongst young people (Dubai Press Club, 2014). There has been a great deal of speculation about the impact of social networking sites (SNS) on user's lives.

There are various reasons and motives behind SNS usage. The basic use of social media according to many people is to merely socialize with the individuals and to sustain connection with others.

Some people use SNS to exhibit and gain knowledge. Others use it as an entertainment source to enjoy one's leisure time since they find it very entraining by using unique applications, while many people use it to stay in touch with friends and to attain social recognition (Okazaki et al., 2014). A considerate number of people use SNS for the sake of chatting and gossips. These people like to talk about other peoples' lives, slander and encourage hearsay in virtual groups.

People do social networking to satisfy four motives (Okazaki, Ph, Rubio, \& Campo, 2012). They expect and retrieve, refine and use information, expand their friendship circle to acquire pleasure and to get entertained and finally to seek psycho-social esteem(Contractor \& DeChurch, 2014). 


\subsection{Information Motive and Gossip Propensity}

Many people use SNS to transmit and gain valuable and material knowledge. The information posted by individuals on SNS help others to provide specific benefits. By exchanging data on social networking sites from one individual additionally helps the other individuals to generate ideas or have chance to clear their uncertainty in regards to anything.

Today social media plays a vital part in exchange of communicable knowledge of something by gossiping with one another. Gossip is an efficient way and frequently the best way to become acquainted with information (Archer-Brown et al., 2012; Collin, Rahilly, Richardson, \& Third, 2011; Rosnow \& Foster, 2005).

It expresses that news discovers individuals rather than individuals discover news. By gossiping one can get new information about the individual about whom one gossips, or check whether others impart one's insight of this individual(Archer-Brown et al., 2012). Gossiping provides individuals to exchange news with each other and make a "social guide" of the earth in which they live (Rosnow, 1977; Van Kleef, De Dreu, \& Manstead, 2010). Gossiping on social media allows individuals to share their knowledge or increase their learning about someone or something.

\subsection{Friendship Motive and Gossip Propensity}

People not only use social networking sites to stay in touch with their existing friends but also to make new friends and be part of the social groups. Social networking sites and computer mediated communications provides extra opportunities to build relationships in limited time as compared to making real life friends(Banerjee, Chandrasekhar, Duflo, \& Jackson, 2014; Kotler \& Keller, 2014; Okazaki et al., 2012). Making friends on internet is quick and easy.Ellison, Steinfield, \& Lampe (2007) define Social Networking Sites as "Virtual social networks".

People seek friendships to avoid the feeling of loneliness and hence, are seen to indulge in the act of gossips. They make groups and pages where all friends are added and these friends talk and discuss about other friends and other people on the social networking sites.

\subsection{Entertainment Motive and Gossip Propensity}

Social networking sites facilitate individual to enjoy their leisure time. The third motive is that of social enjoyment. Social media provides a platform to people to get amusement by gossiping with one another(S. Song, 2012). Gossiping helps people to have ton of fun and can divert oneself as well as other people from routine exercises. Gossiping then is persuaded by the yearning to have a decent time with others. Individuals talk only for the fulfillment of diversion it renders (LAPORTE, 2013; Park, Kee, \& Valenzuela, 2009; Rosnow, 1977; Van Kleef et al., 2010).

\subsection{Social Enhancement Motive and Gossip Propensity}

People want to be recognized in front of other people. It's human trait to seek attention. Many people use Social Networking sites as means to get acknowledged virtually and become the 
centre of attention, they want to be known by all which gives them a feeling of contentment but when this need isn't fulfilled, they may indulge in the practice of gossiping to be the centre of attention(Banerjee et al., 2014; Lin \& Lu, 2011; Park et al., 2009).

They feel like they are important and people come to them and refer to them and talk to them about different things(Hajli, 2013). They feel powerful and acknowledged, which fulfills their motive of being socially accepted and having increased social enhancement.

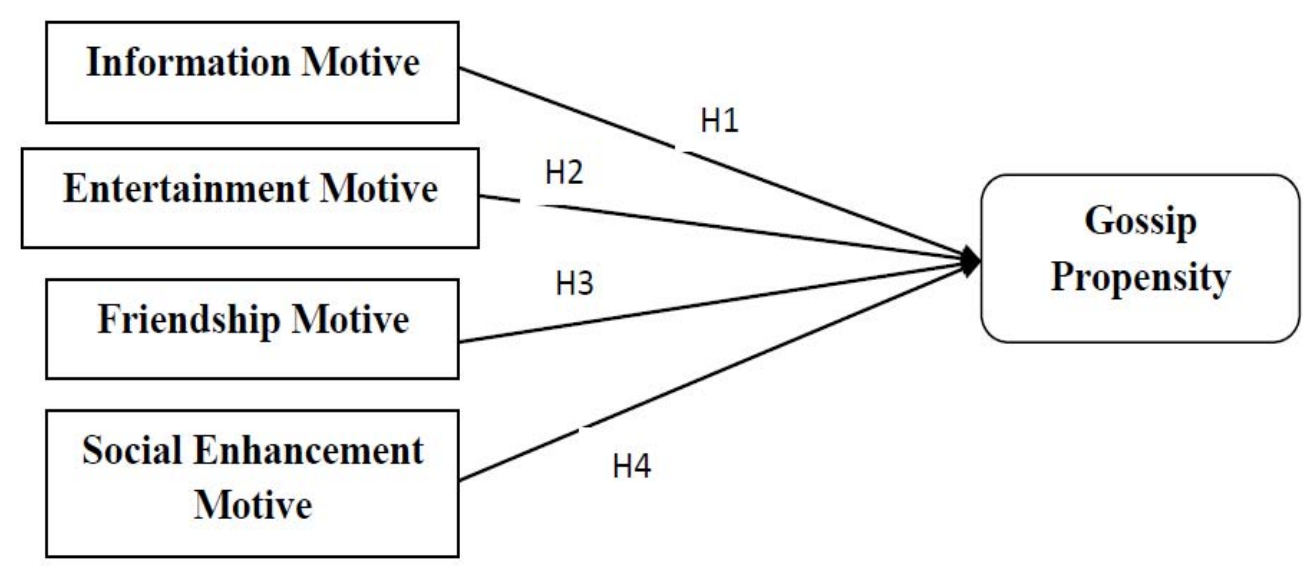

Figure 1. Conceptual Framework

The conceptual framework of the study is given in the figure 1. According to the conceptual framework, the propensity to gossip may be a result of the initial tendency towards information, entertainment, friendship or social enhancement motives.

\section{Methodology}

The current study is quantitative in nature and the data was collected using close ended questionnaire. The fundamental point of this studywas to explore the motives people intend to satisfy by using Social media. This point was accomplished by doing desk research and has been presented in literature review. The second purpose of study was to test the relationship between motives of using social media and people's propensity to gossip. This relationship between independent variables and dependent variable makes present research causal in nature.

UAE is a Diaspora market where the number of immigrants is greater than the number of locals. People living here are from diverse background and this is a multicultural hub. The respondents of our study were people living in Sharjah and Dubai, but belonged from different backgrounds and countries. Considering resource constraints, convenience sampling has been used and 240 respondents were surveyed. The sample size was determined using item-based scaling method. The data was collected from the students and office workers in the Dubai International academic city, various shopping malls and bus stations and also from different offices. The pen and printed questionnaires were given to random people. 


\section{Nl Macrothink}

Journal of Management Research

ISSN 1941-899X

2016, Vol. 8, No. 3

The research has been done by using survey questionnaire as an instrument for data collection. The questionnaire has been borrowed from existing body of knowledge. It is divided into 2 parts where first part is related to the demographics such as age, gender, occupation etc.

The second part incorporates 19 questions amongst which 12 are related to the independent variables and the rest 5 are about the dependent variable. The respondents were asked to mark the correct option according to their preference using a 5 point likert scale where 1 represents strongly disagree and 5 shows strong agreement.

Table 1. Reliability and Validity Analysis

\begin{tabular}{llll}
\hline Variables & Cronbach's alpha & CR & AVE \\
\hline Information Motive & 0.740 & 0.819 & 0.783 \\
\hline $\begin{array}{l}\text { Entertainment } \\
\text { Motive }\end{array}$ & 0.683 & 0.748 & 0.716 \\
\hline $\begin{array}{l}\text { Friendship Motive } \\
\text { Social Enhancement }\end{array}$ & 0.673 & 0.730 & 0.712 \\
\hline Motive & 0.827 & 0.914 & 0.794 \\
\hline Gossip Propensity & 0.743 & 0.827 & 0.739 \\
\hline
\end{tabular}

Reliability Analysis revealed that data has internal consistency as well as composite reliability. See table 1 for the summary of reliability test results.

\section{Results}

The section is devoted to the detailed discussion on the estimations. The section comprises of descriptive statistics, hypothesis testing, parametric statistics assumptions, structural equations modeling and regression results.

\subsection{Descriptive Analysis}

The descriptive analysis revealed that $50.4 \%$ of the respondents were males and $49.6 \%$ were females. These males/females belonged to 5 age groups, wherein $37.5 \%$ of respondent were below 20 years in age. $40.8 \%$ belonged to 20-29years'age group, $13.8 \%$ respondents belonged to 30-39 years in age and 6.3\% were from $40-49$ age groups and last $1.7 \%$ was above 50 years in age.

$68.2 \%$ of the respondents were students and $5.1 \%$ of them were self-employed. $3.4 \%$ were housewives, $22.5 \%$ office workers and the remaining $8 \%$ were unemployed. People use different devices to get online for the purpose of using Social networking sites. $27.5 \%$ of the total respondents use smart devices and $10.8 \%$ of them use personal computers, while $61.3 \%$ of them use both. 
$28.9 \%$ of the respondents regularly communicate with only $1-10$ people on social networking sites. $25.9 \%$ respondents have $11-20$ individuals as regular contacts. $16.7 \%$ of the total respondents regularly contact with $20-30$ people while $28.5 \%$ respondents have regular contact with more than 30 individuals.

Lastly, as far as frequency of usage is concerned, majority $(65.7 \%)$ of respondents are using social media for more than 5 years while only $32 \%$ have been using it for last 2-3 years. $7.5 \%$ of the respondent's access social networking sites few times a month, while $6.3 \%$ of them use it several times a month. $8.3 \%$ of the respondents use SNS few times a week and same number of people uses it several times of week. $23.3 \%$ go online few times a day and the remaining $46.3 \%$ of the respondents' access SNS several times a day.

Table 2 illustrates that means values of all constructs. Information motive (IM1, IM2, and IM3) states intentions of using social media for the purpose of collecting, refining, using and retrieving information as all items are indicating towards the somewhat agreed ratio. As friendship motive, FM1 is greater than the 4.1 and it positions strongly agree ratio among individual and tend to support that social networking sites helps them to stay in touch with others. Similarly, FM2, FM3 and FM4 is greater than 3.1which direct towards the agree scale because mostly the purpose of using social networking sites by people is to stay in touch with each other's. Social networking sites enable individuals enjoy their leisure timeand this is proved through the mean value of EM1, EM2 and EM3 which is above the 3.1 indicating towards the somewhat agree scale. Self-recognition plays an important role in social networking sites as it facilitates individuals to create a positive impression about them in front of others. This clarifies that SM1, SM2 and SM3 items are agreed as it is above the 3.1 value. Gossiping play an important role in social networking sites because individuals do gossip for many reasons. This demonstrates that gossip propensity, GP1 direct the positive relationship but GP2 indicate the neutral relationship because some of people don't like to know what's going on in other people's lives. Similarly, GP3, GP4, GP5 and GP6 items is directed positively towards the agree scale as it is greater than the 3.1 value and proves that people like to share what they observe and inform others about it by gossiping. Hence, the mean values of independent and dependent variable items are indicating agreed relationship between social networking sites and gossip propensity. 
Table 2. Means Analysis

\begin{tabular}{|c|c|c|c|}
\hline & Mean & Skewness & Kurtosis \\
\hline IM1 & 3.7792 & -.340 & .122 \\
\hline IM2 & 3.7125 & -.490 & .603 \\
\hline IM3 & 3.7167 & -.659 & .450 \\
\hline FM1 & 4.4417 & -.984 & .401 \\
\hline FM2 & 3.5208 & -.461 & -.304 \\
\hline FM3 & 3.5542 & -.393 & -.374 \\
\hline FM4 & 3.9333 & -.815 & .666 \\
\hline EM1 & 3.9167 & -.503 & .129 \\
\hline EM2 & 3.8875 & -.676 & .307 \\
\hline EM3 & 3.5958 & -.248 & -.359 \\
\hline SM1 & 3.5333 & -.521 & .032 \\
\hline SM2 & 3.3500 & -.177 & .177 \\
\hline SM3 & 3.5625 & -.347 & -.029 \\
\hline GP1 & 3.5917 & -.604 & -.163 \\
\hline GP2 & 3.1458 & -.179 & -.720 \\
\hline GP3 & 3.3917 & -.632 & .209 \\
\hline GP4 & 3.8375 & -.847 & .937 \\
\hline GP5 & 3.3250 & -.267 & -.551 \\
\hline GP6 & 3.3250 & -.426 & -.517 \\
\hline
\end{tabular}

\subsection{Hypotheses Testing}

In order to test hypotheses, researchers (Byrne, 2013; Hair, Black, Babin, \& Anderson, 2014; Keppel, 1982; Saunders, Lewis, \& Thornhill, 2012) suggest the use of parametric tests because of greater accuracy, authenticity, and inferential power. However, parametric statistics require certain assumptions to be checked in order to proceed further. Any violation of these assumptions does not allow researchers to move ahead and thus, non-parametric tests will be utilized. 
4.2.1. Assumptions of Parametric statistics

As illustrated in Table 3, parametric statistical testing requires the data to have 6 characteristics. Firstly, the scale used to collect data shall have internal consistency and composite reliability. It has been tested using Cronbach Alpha, CR, AVE, and MSV. The results (Table 1) revealed a reliable and valid measurement scale. Secondly, parametric statistics require sample adequacy and was tested using item-based rule, KMO \& Bartlett's test, and HOELTER test. The results indicated data adequacy and sufficiency. Thirdly, data shall be normally distributed and it can be tested using Skewness and Kurtosis as well as Kolmogorove-Smirnov test. All of the values of skewness and kurtosis (Table 2) are within the range of +1 to -1 . Hence, data was found normally distributed. Fourthly, parametric statistics require data to have linearity and is usually tested using residual plots with Fitline. Residual plot indicated a perfectly linear line and heteroskedasticity was absent. A very important assumption of causal analysis is absent of multicollinearity and is usually tested using Tolerance values, VIF values, and condition Index. Results obtained in regression indicated no multicollinearity. Lastly, there shall be no correlation among independent variables and it is tested through Durbin Watson test. When applied, value of 1.938 indicated no presence of autocorrelation. 
Table 3. Assumptions of Parametric tests

\begin{tabular}{|c|c|c|c|}
\hline Analysis / Test & Technique & Finding & Conclusion \\
\hline \multirow{4}{*}{$\begin{array}{l}\text { 1. Reliability } \\
\text { Analysis }\end{array}$} & - Cronbach Alpha & - $\quad$ Above 0.59 . & \multirow{4}{*}{$\begin{array}{l}\text { - Scale is Reliable } \\
\text { and has no } \\
\text { validity } \\
\text { problem. }\end{array}$} \\
\hline & - $\mathrm{CR}$ & - Above 0.70 & \\
\hline & - AVE & - Above 0.50 & \\
\hline & - MSV & - Less than AVE & \\
\hline \multirow{3}{*}{ 2. Sample Adequacy } & - Item-Based Rule & $\begin{array}{l}19 * 10= \\
190<240\end{array}$ & \multirow{3}{*}{$\begin{array}{l}\text { - Sample Size is } \\
\text { sufficient and } \\
\text { Adequate }\end{array}$} \\
\hline & $\begin{array}{l}\text { - KMO \& Bartlett's } \\
\text { Test }\end{array}$ & $\begin{array}{ll}\text { - } & 0.837 \\
\text { - } & \mathrm{P}=0.00 \\
\end{array}$ & \\
\hline & $\begin{array}{l}\text { - HOELTER }(0.05 \\
\& 0.01)\end{array}$ & - $\quad 145 \& 178<240$ & \\
\hline 3. Data Normality & $\begin{array}{ll}\text { - } & \text { Skewness \& } \\
& \text { Kurtosis. } \\
\text { - } & \text { Histograms. }\end{array}$ & $\begin{array}{l}\text { - Values are } \\
\text { between }-1 \text { to }+1 \text {. }\end{array}$ & $\begin{array}{l}\text { - Data is normally } \\
\text { distributed. }\end{array}$ \\
\hline \multirow{3}{*}{ 4. Multicollinearity } & - $\quad$ Tolerance $\left(>1-\mathrm{R}^{2}\right)$ & $\begin{array}{l}\text { Tolerance values } \\
\text { are above } 1-\mathrm{R}^{2} \text {. }\end{array}$ & \multirow{3}{*}{$\begin{array}{l}\text { - } \quad \text { No } \\
\text { multicollinearity }\end{array}$} \\
\hline & - VIF & $\begin{array}{l}\text { - VIF values are } \\
\text { below } 3 \text {. }\end{array}$ & \\
\hline & - Condition Index & $\begin{array}{l}\text { - Values are below } \\
30 .\end{array}$ & \\
\hline 5. Heteroskedasticity & $\begin{array}{l}\text { - Residuals Plot with } \\
\text { Fit Line }\end{array}$ & - Linear line & $\begin{array}{l}\text { - No } \\
\text { Heteroskedastici } \\
\text { ty }\end{array}$ \\
\hline 6. Autocorrelation & - Durbin-Watson & 1.729 & $\begin{array}{l}\text { - } \\
\text { Autocorrelation }\end{array}$ \\
\hline
\end{tabular}

\subsubsection{Regression Analysis}

This research study aims to test a causal relationship between motives of social networking and gossip propensity. This relationship was tested using multiple regressions. Significance value ( $p=0.000$ ) which is below the 0.05 indicating existence of causal relationship exists between independent and dependent variables. $\mathrm{R}^{2}$-value $(0.508)$ proves a $50.8 \%$ change in gossip propensity because of 4 independent variables. Values of coefficient reveal a positive and direct relationship between 3 motives (EM, FM, and SM) of using social media and gossip propensity. The table 4 shows the relationship between the independent and dependent variables wherein the $p$ - value of information motive is .686 which is higher than the 0.05 ; it 


\section{Macrothink}

Journal of Management Research

ISSN 1941-899X

2016, Vol. 8, No. 3

demonstrates that relationship does not exist between both variables. P-value of friendship motive is .047 which is lower than the 0.05 proving that people who use social media to stay in touch with others do gossip with one another. Entertainment motive and social enhancement conduct a higher relationship between independent and dependent variable by obtaining a p-value as .001 and .000 respectively. This exemplifies that people use social networking sites to get entertained and become recognized among other by gossiping with other individuals. T-values represent direction of influence of Independent variables on dependent variables, and very interestingly, information motive is negatively associated with gossip propensity indicating an inverse relationship. It means any increase in information motive will lead to a decrease in gossip propensity. However, all other motives are directly proportional to gossip propensity.

Un-standardized coefficients signify the change being caused by motives of social networking in gossip propensity. Information motive brings a change of only $2.7 \%$ in gossip propensity which is negligible and states that people do not gossip when there are using it for informational purposes. Friendship motive brings $13.5 \%$ change in dependent variable which encompass that people do gossip with other people to stay in touch. Entertainment motive and social enhancement motives bring change of $22.1 \%$ and $41.4 \%$ subsequently. It proves that basic reason to gossip is to get recognized by establishing a good impression of them among other people. 


\section{Il Macrothink}

Table 4. Regression Analysis

\begin{tabular}{lllll}
\hline Model & R & R Square & Adjusted R Square & Sig. \\
\hline 1 & $.713^{\mathrm{a}}$ & .508 & .498 & .000 \\
\hline $\mathbf{F}=48.621$ & &
\end{tabular}

$\mathbf{F}=48.621$

$\underline{\text { Coefficients }}^{\mathrm{a}}$

\begin{tabular}{|c|c|c|c|c|c|c|}
\hline \multirow[t]{2}{*}{ Mode } & & \multicolumn{2}{|c|}{$\begin{array}{l}\text { Unstandardized } \\
\text { Coefficients }\end{array}$} & \multirow{2}{*}{$\begin{array}{l}\text { Standardized } \\
\text { Coefficients } \\
\text { Beta } \\
\end{array}$} & \multirow[t]{2}{*}{$\mathbf{T}$} & \multirow[t]{2}{*}{ Sig. } \\
\hline & & B & Std. Error & & & \\
\hline \multirow{5}{*}{1} & (Constant) & .519 & .263 & .050 & 1.970 & .050 \\
\hline & IM & -.027 & .067 & -.686 & -.404 & .686 \\
\hline & $\mathrm{FM}$ & .135 & .067 & .047 & 1.998 & .047 \\
\hline & EM & .221 & .066 & .001 & 3.364 & .001 \\
\hline & SM & .414 & .053 & .000 & 7.753 & .000 \\
\hline
\end{tabular}

\subsubsection{Structural Equation Modelling}

In order to better understand impact of social media motives on gossip propensity, researchers applied structure equation modeling and regression model with standardized estimates is shown in figure 2.

Structural regression model has been found exhibiting goodness-of-Fit. Byrne (2013); Hair, Black, Babin, \& Anderson (2014); and Kline (2011) suggest CMIN/DF $(\leq 3.0)$, CFI $(\geq 0.9)$, RMSEA $(\leq 0.05)$, GFI $(\geq 0.9)$ and AGFI $(\geq 0.8)$. The results (shown in Table 4.4) clearly prove goodness-of Fit of hypothesized model as value of all measures are greater than bottom-line values $(\mathrm{CMIN} / \mathrm{DF}=1.613, \mathrm{P}=0.00, \mathrm{CFI}=0.934, \mathrm{RMSEA}=0.053$ and $\mathrm{AGFI}=$ $0.91)$

Three hypotheses have been proved as P-Value for all causal relationships are below 0.05 and hence, represent strong association. However, hypothesis depicting relationship between information motive and gossip propensity has been rejected because of insignificant $p$-Value. The $\beta$ Values for $\mathrm{H} 1$ is 0.006 representing a very negligible change in gossip propensity. However, estimates of all other variables are quite healthy and show significant change being caused in gossip propensity. The figure 2 has been provided here to present the factor analysis of the whole study taking into consideration the variables and the latent variables under study. 


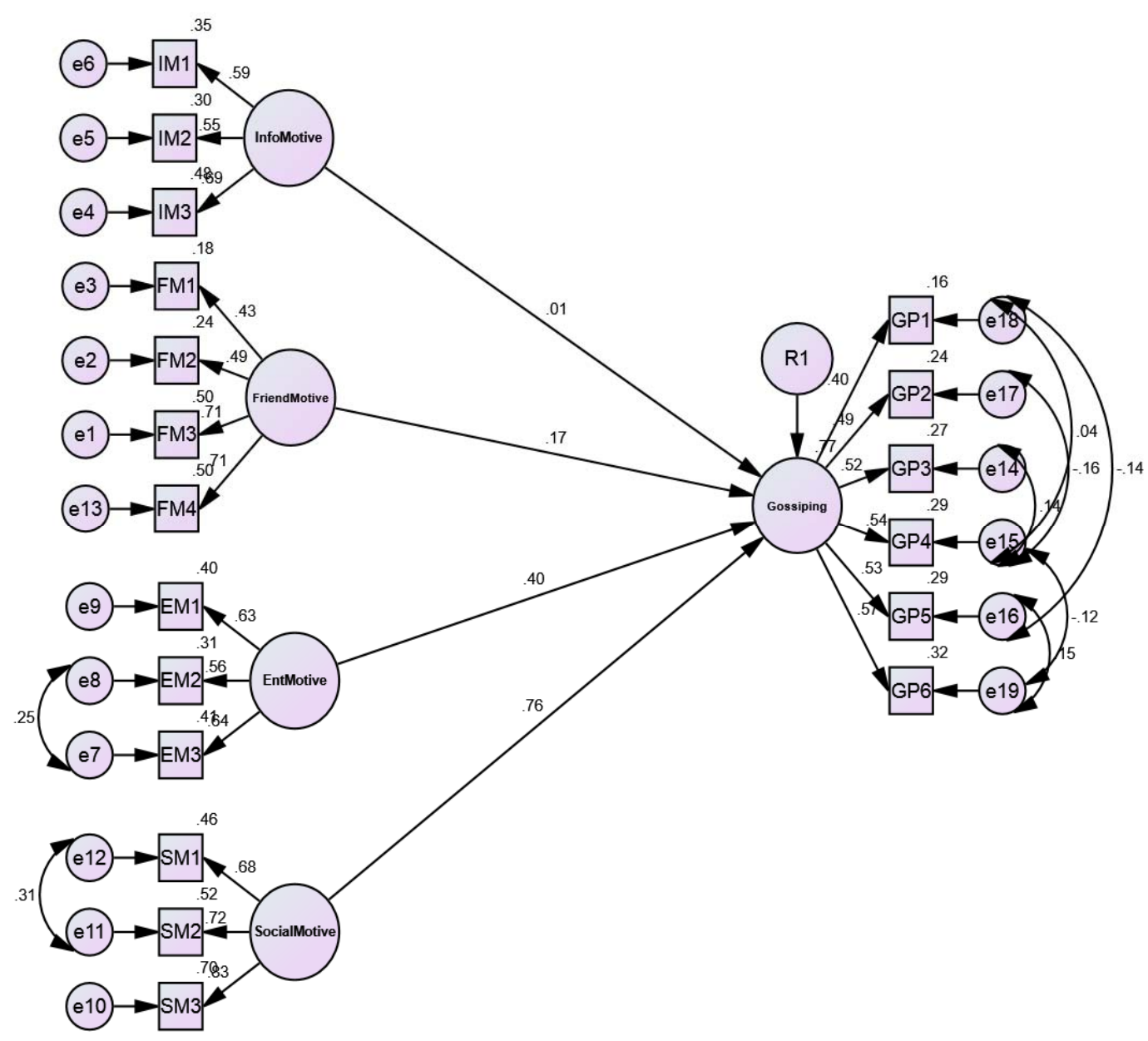

Figure 2. Regression Model with Standardized Estimates

Table 5. Goodness-of-Fit Statistics for Measurement model

\begin{tabular}{lrrrrr}
\hline Model & NPAR & CMIN & DF & P & CMIN/DF \\
\hline Default model & 56 & 216.143 & 134 & .000 & 1.613 \\
Saturated model & 190 & .000 & 0 & & \\
Independence model & 19 & 1411.506 & 171 & .000 & 8.254 \\
& \multicolumn{7}{c}{ Baseline Comparisons } \\
\multicolumn{1}{c}{ NFI } & RFI & IFI & TLI & CFI \\
Model & Delta1 & rho1 & Delta2 & rho2 & \\
Default model & .847 & .805 & .936 & .915 & .934 \\
Saturated model & 1.000 & & 1.000 & & 1.000 \\
Independence model & .000 & .000 & .000 & .000 & .000 \\
& \multicolumn{7}{c}{ RMSEA } & & & \\
Model & RMSEA & LO 90 & HI 90 & PCLOSE & \\
Default model & .053 & .040 & .066 & .344 & \\
Independence model & .182 & .173 & .191 & .000 & \\
\hline
\end{tabular}


Table 6. Regression Weights

\begin{tabular}{|c|c|c|c|c|}
\hline Hypotheses & & & Estimate & $\mathbf{P}$ \\
\hline Gossiping & $<---$ & Information Motive & .006 & .929 \\
\hline Gossiping & $<---$ & Friendship Motive & .111 & .034 \\
\hline Gossiping & $<---$ & Entertainment Motive & .317 & $* * *$ \\
\hline Gossiping & $<---$ & Social Enhancement Motive & .484 & $* * *$ \\
\hline
\end{tabular}

\section{Discussion}

Causal analysis revealed that users who do networking on social media for the purpose of seeking entertainment, increasing their social sphere of friends and acquaintances, for the purpose of attaining psycho-social value from their circle of influence tend to have higher gossip propensity. However, individual visiting social media to fetch information to be utilized for job specific, organization specific or task specific purposes tend to be more focus and thus are not inclined towards gossiping. The findings are very consistent with previous research studies conducted in related domains across various sectors.

\section{Conclusion and Recommendations}

Researchers like (Bommel, Edelman, \& Ungerman, 2014; Court, Elzinga, Mulder, \& Vetvik, 2009) suggest that marketers focus on job which consumers want to satisfy and the mediums consumers have access to in order to actively access the information about the brands, services and ideas and to refine, disseminate and use this information for the purpose of making decisions.

Present research concludes the motive the consumers have when they are accessing social media and the very first hypothesis suggested a more focus and concentrated browsing when consumers access social media for information purposes. Marketers need to design the customer's interface according to consumers' preferences in order to increases consumers' engagement to generate buzz about their campaign and brands, to increase knowledge and learning about consumers and thus make their targeting more concentrated and accurate. Companies can increase buzz and positive word of mouth which may lead their campaign go viral. For example, Haagen-Dazs associated themselves with a cause and created "Save the Honey bees" campaign, which consisted of an opera and a plantation of flower seeds by consumers when they received it by New York Times. Consumers became more engaged, started posting user generated videos on dedicated social platforms and the whole "save the honeybees" campaign becomes a social phenomenon. Haagen-Dazs achieved their annual target of 12500 social impacts within 6 weeks.

Ford, when introduced Fiesta model asked 100 influencers to test drive the cars and provide reviews on dedicated social networks. Every influencer has to complete a mission and the whole campaign went viral. Ford witnessed 6.5 million views on YouTube and received 
50000 requests for information about their models from non- ford drivers. When the car was finally launched, 10000 cars were sold in the first week that's how company can create buzz about the brands they are launching.

Companies can learn about what consumers think, how they feel, how they act and how they perceive and react. Nike, Zara, Google, Adidas and many other companies have very sophisticated data analytics and are harnessing their power by data. Pepsi.co created a campaign for the brand they use social networks to gather insights about a consumers use the brands and what they prefer in it through 'Dewmocracy' campaign. They were able to sell 36 million cases of dew in the next 2 years.

Companies can launch location specifics offer and promotions. Levis Toss offers location specific deals in which 400 consumers advocated the brand which led 1600 people to go to stores and thus $89 \%$ increases in sale was witnessed.

Companies need to monitor their activities, brands and especially campaign on social networking sites. Companies need to track the trends which are emerging in both; business to consumer setting as well as in business to business setting.

Lays started a campaign by trending \#LittleJoysOfLife on Twitter. The more the people tweeted using the hashtag the more chance they had to win free one month supply of lays. This helped lays to advertise themselves with the help of consumers itself and later enjoyed the benefits in terms of increase in sales and awareness.

Similarly Colgate conduct a Facebook contest by launching an interactive outdoor campaign, featuring pictures of its Facebook followers smiling in support of children's charity Barnardo's. The campaign aims to collect one million "smiles" throughout the summer. The brand has promised to donate $£ 100,000$ to Barnardo's when that target has been reached. They asked their followers to upload a smiling picture of themselves and upload it in their Facebook page. By adopting this campaign Colgate was able to achieve their target and creates brand awareness through social networking sites.

\section{Future Research Areas}

The researches should increase the sample size and adopt probability sampling technique. It is further recommended that respondents of the study should be from a wider sector and in-depth study about each of the sector should be done in order to get the detailed information about the respondents of each sector. The researchers can further study the relationship between gossip propensity and increased social engagement. Relationship between gossip propensity and trust should be tested that whether gossip has an impact on people having trust on each other or not. Does it affect negatively or positively? Gossip propensity can also be related to increase in word of mouth leading towards increased brand advocacy and loyalist behaviors. However, it needs to be tested in future research studies. 


\section{References}

Archer-Brown, C., Piercy, N., \& Joinson, A. (2012). Examining the information value of virtual communities: Factual versus opinion-based message content. Journal of Marketing Management, 29(3-4), 421-438. http://doi.org/10.1080/0267257X.2012.732599

Asiegbu, I. F., Powei Daubry M, \& Iruka, C. (2012). Consumer Attitude: Some Reflections on Its Concept, Trilogy, Relationship with Consumer Behavior, and Marketing Implications. European Journal of Business and Management, 4(13), 38-50. Retrieved from http://www.iiste.org/Journals/index.php/EJBM/article/viewFile/2702/2726

Banerjee, A., Chandrasekhar, A. G., Duflo, E., \& Jackson, M. O. (2014). Gossip: Identifying Central Individuals in a Social Network. Retrieved from http://arxiv.org/abs/1406.2293

Bommel, E. Van, Edelman, D., \& Ungerman, K. (2014). Digitizing the consumer decision journey. McKinsey \& Company, (June), 1-8. Retrieved from http://www.mckinsey.com/insights/marketing_sales/digitizing_the_consumer_decision_journ ey

Byrne, B. M. (2013). Structural Equation Modeling With AMOS: Basic Concepts, Applications, and Programming, Second Edition. Routledge. Retrieved from https://books.google.com/books?id=0cHbAAAAQBAJ\&pgis=1

Clegg, S. R., \& van Iterson, A. (2009). Dishing the dirt: gossiping in organizations. Culture and Organization, 15(3-4), 275-289. http://doi.org/10.1080/14759550903119293

Collin, P., Rahilly, K., Richardson, I., \& Third, A. (2011). Literature Review: The Benefits of Social Networking Services, (April), 29. Retrieved from http://www.fya.org.au/wp-content/uploads/2010/07/The-Benefits-of-Social-Networking-Serv ices.pdf

Contractor, N. S., \& DeChurch, L. a. (2014). Integrating social networks and human social motives to achieve social influence at scale. Proceedings of the National Academy of Sciences, 111. http://doi.org/10.1073/pnas.1401211111

Court, D., Elzinga, D., Mulder, S., \& Vetvik, O. J. (2009, June). The consumer decision journey. McKinsey Quarterly, 3, 96-107. 12p. 1 Color Photograph. http://doi.org/http://dx.doi.org/10.1108/EUM0000000005155

Dubai Press Club. (2014). 2014 UAE SOCIAL MEDIA OUTLOOK: Increasing Connectivity Between Government and Citizen. Dubai.

Dunbar, R. I. M. (2004). Gossip in Evolutionary Perspective. Review of General Psychology, 8(2), 100-110. http://doi.org/10.1037/1089-2680.8.2.100

Dunbar, R. I. M., Arnaboldi, V., Conti, M., \& Passarella, A. (2015). The structure of online social networks mirrors those in the offline world. Social Networks, 43, 39-47. http://doi.org/10.1016/j.socnet.2015.04.005 
Ellison, N. B., Steinfield, C., \& Lampe, C. (2007). The Benefits of Facebook "Friends:" Social Capital and College Students' Use of Online Social Network Sites. Journal of Computer-Mediated Communication, 12(4), 1143-1168. http://doi.org/10.1111/j.1083-6101.2007.00367.x

Griffith, E. (2015, April). Snitches' brew. Fortune, 46-48.

Hair, J. F., Black, W. C., Babin, B. J., \& Anderson, R. E. (2014). Multivariate Data Analysis (7th ed.). EdinBurgh: Prentice-Hall.

Hajli, M. N. (2013). A study of the impact of social media on consumers. International Journal of Market Research, 56(3), 287-404. http://doi.org/10.2501/IJMR-2014-000

Keppel, G. (1982). Design and analysis: A researcher's handbook (Vol. 2nd). Englewood Cliffs. NJ: Prentice-Hall. $\quad$ Retrieved from http://search.ebscohost.com/login.aspx?direct=true\&db=epref\&AN=DARH.KEPPEL.PREN TICEHALL.AIHB\&site=ehost-live

Kline, R. B. (2011). Principles and Practice of Structural Equation Modeling. Guilford Press. Retrieved from https://books.google.com/books?id=-MDPILyu3DAC\&pgis=1

Kniffin, K. M., \& Sloan Wilson, D. (2010). Evolutionary Perspectives on Workplace Gossip: Why and How Gossip Can Serve Groups. Group \& Organization Management, 35(2), 150-176. http://doi.org/10.1177/1059601109360390

Kniffin, K. M., \& Wilson, D. S. (2005). Utilities of gossip across organizational levels: Multilevel selection, free-riders, and teams. Human Nature, 16(3), 278-292. http://doi.org/10.1007/s12110-005-1011-6

Kotler, P., \& Keller, K. (2014). Marketing Management Plus 2014 Mymarketinglab with Pearson Etext -- Access Card Package (14th ed.). Pearson Education. Retrieved from https://books.google.com/books?id=86HKoAEACAAJ\&pgis=1

Kurland, N. B., \& Pelled, L. H. (2000). Passing the word: Toward a model of gossip and power in the workplace. Academy of Management Review, 25(2), 428-438. http://doi.org/10.5465/AMR.2000.3312928

LAPORTE, N. (2013). A TALE OF TWO NETFLIX. Fast Company, (177), 31-32. Retrieved from http://search.ebscohost.com/login.aspx?direct=true \&db=buh\&AN=88193589\&site=ehost-liv e

Lin, K. Y., \& Lu, H. P. (2011). Why people use social networking sites: An empirical study integrating network externalities and motivation theory. Computers in Human Behavior, 27(3), 1152-1161. http://doi.org/10.1016/j.chb.2010.12.009

Linde, C. (2001). Narrative and social tacit knowledge. Journal of Knowledge Management, 5(2), 160-171. http://doi.org/10.1108/13673270110393202 
McAndrew, F. T., Bell, E. K., \& Garcia, C. M. (2007). Who Do We Tell and Whom Do We Tell On? Gossip as a Strategy for Status Enhancement. Journal of Applied Social Psychology, 37(7), 1562-1577. http://doi.org/10.1111/j.1559-1816.2007.00227.x

Okazaki, S., Ph, D., Rubio, N., \& Campo, S. (2012). Do Online Gossipers Promote Brands? Cyberpsychology, Behavior and Social Networking, 00(00), 1-8. http://doi.org/10.1089/cyber.2012.0283

Okazaki, S., Rubio, N., \& Campo, S. (2014). Gossip in social networking sites - Why people chitchat about ad campaigns. International Journal of Market Research, 56(3), 317-340. http://doi.org/10.2501/IJMR-2014-022

Park, N., Kee, K. F., \& Valenzuela, S. (2009). Being immersed in social networking environment: Facebook groups, uses and gratifications, and social outcomes. Cyberpsychology \& Behavior : The Impact of the Internet, Multimedia and Virtual Reality on Behavior and Society, 12(6), 729-733. http://doi.org/10.1089/cpb.2009.0003

Rosnow, R. L. (1977). Gossip and Marketplace Psychology. Journal of Communication, 27(1), 158-163. http://doi.org/10.1111/j.1460-2466.1977.tb01811.x

Rosnow, R. L., \& Foster, E. K. (2005). We should distinguish between rumor and gossip, as each appears to function differently in its pure state. Retrieved from http://www.apa.org/science/about/psa/2005/04/gossip.aspx

Saunders, M., Lewis, P., \& Thornhill, A. (2012). Research Methods for Business Students. Business (Vol. 5th).

Song, L. Z., Song, M., \& Di Benedetto, C. A. (2009). A staged service innovation model. Decision Sciences, 40(3), 571-599.

Song, S. (2012, January). The Upside of Gossip and psychological benefits. The Time Magazine. Retrieved from http://healthland.time.com/2012/01/19/the-upside-of-gossip-social-and-psychologicalbenefits/

Van Kleef, G. A., De Dreu, C. K. W., \& Manstead, A. S. R. (2010). An interpersonal approach to emotion in social decision making: The emotions as social information model. Advances in Experimental Social Psychology, 42, 45-96.

Vohs, K. D., Baumeister, R. F., Schmeichel, B. J., Twenge, J. M., Nelson, N. M., \& Tice, D. M. (2014). Making choices impairs subsequent self-control: a limited-resource account of decision making, self-regulation, and active initiative. 